\title{
revistadechimie.ro
}

Vol. 72 / Number 1 / Year 2021
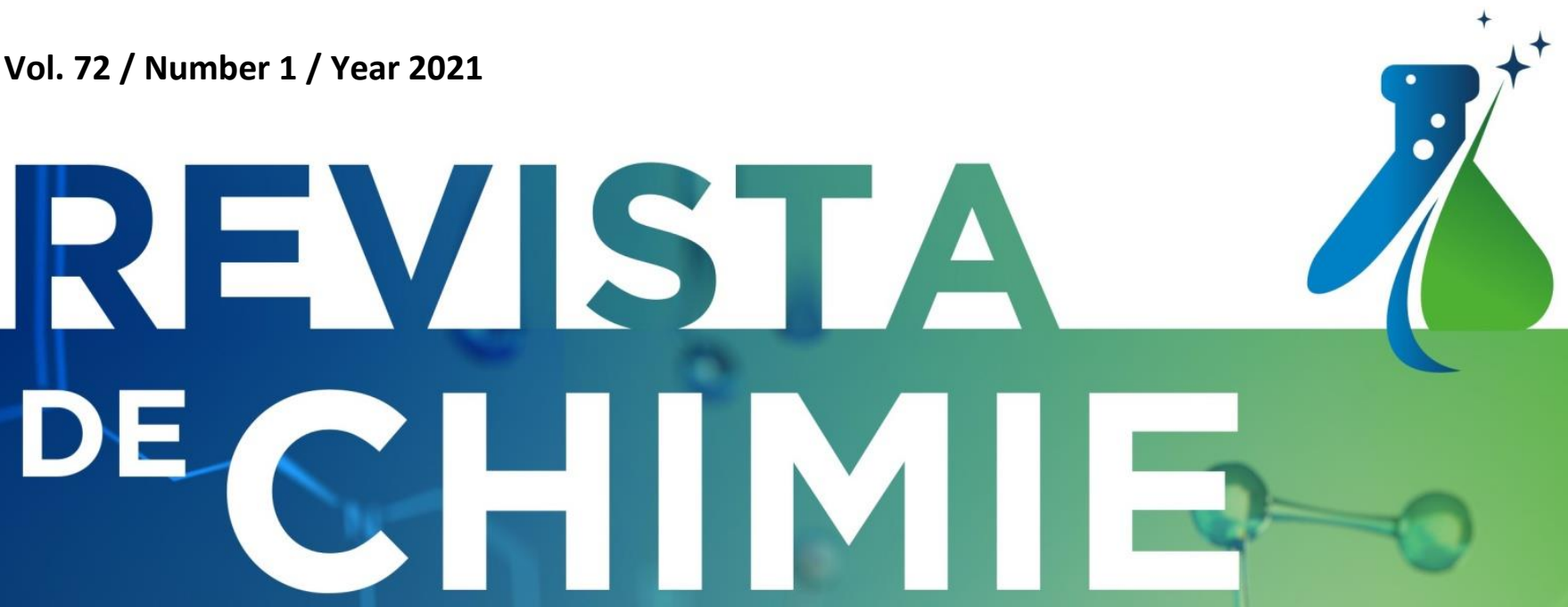

Chemistry Sciences

Chemical and Biochemical Engineering

Environmental Chemistry and Engineering

Chemistry Application in Food, Nutrition, Agriculture

Medical and Pharmaceutical Chemistry

Materials

\section{JANUARY 2021}

Print ISSN: 0034-7752 / Online ISSN: 2668-8212 
REVISTA DE CHIMIE FOUNDED IN 1949

BUCURESTI ROMANIA

EDITORIAL BOARD

Editor-in-Chief:

Gabriel Lucian RADU

Politehnica University of Bucharest, Romania

Editorial Manager:

Ion ANDRONACHE

Revista de Chimie SRL, Bucharest, Romania

\section{EDITORS:}

Ionel MANGALAGIU - Chemistry Sciences

Alexandru Ioan Cuza University, Iasi, Romania

Irinel Adriana BADEA - Chemistry Sciences University of Bucharest, Romania

Costin Sorin BILDEA - Chemical and Biochemical Engineering

Politehnica University of Bucharest, Romania

Ioana FECHETE - Chemical and Biochemical Engineering Université de Technologie de Troyes, France

Gheorghe NECHIFOR - Environmental Chemistry and Engineering Politehnica University of Bucharest, Romania

Simona Gabriela BUNGAU - Environmental Chemistry and Engineering University of Oradea, Romania

Adela PINTEA - Chemistry Application in Food, Nutrition, Agriculture University of Agricultural Sciences and Veterinary Medicine Cluj-Napoca, Romania

Gabriela RAPEANU - Chemistry Application in Food, Nutrition, Agriculture Dunarea de Jos University of Galati, Romania

Gabriel Ovidiu BRATU - Medical and Pharmaceutical Chemistry

Carol Davila University of Medicine and Pharmacy, Bucharest, Romania

Camelia DIACONU - Medical and Pharmaceutical Chemistry

Carol Davila University of Medicine and Pharmacy, Bucharest, Romania

Maria CAZACU - Materials

Petru Poni Institute of Macromolecular Chemistry, Iasi, Romania

Iulian ANTONIAC - Materials

Politehnica University of Bucharest, Romania 
ASOCIATE EDITORS:

Lotfi ALEYA

Université de Franche-Comté, France

Patrick Da COSTA

Sorbonne Universite, France

Remi CHAUVIN

University of Toulouse, France

Huaqiao University, Xiamen Campus, China

Giuseppe GATTUSO

University of Messina, Italy

Andrei JITIANU

Lehman College of The City University of New York, USA

Piotr KURCOK

Centre of Polymer and Carbon Materials Polish Academy of Sciences, Poland

Bouchta SAHRAOUI

University of Angers, UFR Sciences

Institute of Sciences and Molecular Technologies of Angers, France

Yanzhong ZHANG

College of Chemistry, Chemical Engineering \& Biotechnology Donghua University, China

\section{EDITORIAL ADVISORY BOARD:}

\section{Sanda ANDREI}

University of Agricultural Sciences and Veterinary Medicine, Cluj-Napoca, Romania

Narcis BARSAN

Vasile Alecsandri University of Bacau, Romania

\section{Ede BODOKI}

Iuliu Hatieganu University of Medicine \& Pharmacy, Cluj-Napoca, Romania

Andreea BUNEA

University of Agricultural Sciences and Veterinary Medicine, Cluj-Napoca, Romania

Ioan CALINESCU

Politehnica University of Bucharest, Romania

Simona CAPRARESCU

Politehnica University of Bucharest, Romania

Otilia CINTEZA

University of Bucharest, Romania

Simona CLICHICI

University of Medicine and Pharmacy, Cluj-Napoca, Romania

Carolina CONSTANTIN

Victor Babes National Institute, Bucharest, Romania

Lucian Octav COPOLOVICI

Aurel Vlaicu University, Arad, Romania 


\section{Calin Cristian CORMOS}

Babeş-Bolyai University, Cluj Napoca, Romania

\section{Dana CULITA}

Institute of Physical Chemistry Ilie Murgulescu, Bucharest, Romania

Andrei DANET

University of Bucharest, Romania

Iulia Gabriela DAVID

University of Bucharest, Romania

\section{Gyorgy DEAK}

INCDPM, Bucharest, Romania

Kamel EARAR

Dunarea de Jos University of Galati, Romania

Petru FILIP

C. D. Nenitescu Institute of Organic Chemistry, Bucharest, Romania

\section{Anca Irina GALACTION}

University of Medicine and Pharmacy Grigore T. Popa, Iasi, Romania

Maria HARJA

Tehnical University Gheorghe Asachi, Iasi, Romania

\section{Cosmin JINESCU}

Politehnica University of Bucharest, Romania

Vasile LAVRIC

Politehnica University of Bucharest, Romania

\section{Simona Carmen LITESCU}

National Institute for Biological Sciences, Bucharest, Romania

\section{Cristian MATEI}

Politehnica University of Bucharest, Romania

\section{Florin MICULESCU}

Politehnica University of Bucharest, Romania

Maria MOHORA

Carol Davila University of Medicine and Pharmacy, Bucharest, Romania

\section{Lucia MUTIHAC}

University of Bucharest, Romania

Denisa NISTOR

Vasile Alecsandri University of Bacau, Romania

\section{Octavian OLARU}

Carol Davila University of Medicine and Pharmacy, Bucharest, Romania

Eliza OPREA

University of Bucharest, Romania

\section{Ovidiu OPREA}

Politehnica University of Bucharest, Romania

Cristian Valeriu PIRVU

Politehnica University of Bucharest, Romania 


\section{Ileana RAU}

Politehnica University of Bucharest, Romania

\section{Sonia SOCACI}

University of Agricultural Sciences and Veterinary Medicine, Cluj-Napoca, Romania

Bogdan SOCEA

Carol Davila University of Medicine and Pharmacy, Bucharest, Romania

Irina STOIAN

Carol Davila University of Medicine and Pharmacy, Bucharest, Romania

Emanuel VAMANU

University of Agronomical Sciences and Veterinary Medicine, Bucharest, Romania

Camelia VIZIREANU

Dunarea de Jos University of Galati, Romania

\section{Laurian VLASE}

University of Medicine and Pharmacy Iuliu Hatieganu, Cluj Napoca, Romania

\section{Maria ZAHARESCU}

Institute of Physical Chemistry Ilie Murgulescu, Bucharest, Romania

Romanian Academy

\section{PUBLISHER STAFF:}

Alice CRISTEA - Manager

Elena ANDRONACHE - IT

Monica BALUTA - Editing

Iuliana GHITA - Accounting

Impact factor 2019: 1.755 
CONTENTS

$1 / 2021$

MIHAI IORDOC, GEORGIANA MARIN, GEORGETA STOIANOVICI, PAULA PRIOTEASA, CRISTINEL BALAN, MARIAN GUTA, RADU FURTUNA

Increasing Corrosion Resistance of Pressure Vessels at the Hydrostatic Pressure Testing by Using Inhibitors. .1

NOOR SABEEH MAJEED, HUSSEIN A. ALABDLY, HUSSAM NADUM ABDALRAHEEM AL ANI, DUMITRU PASCU, AURELIA CRISTINA NECHIFOR

Study the Effect of Gum Arabic and Triton X-100 on Stability and Thermal Conductivity of ZnO/ethylene

Glycol Nanofluids.

GRÉGORIO CRINI, CORINA BRADU, CESARE COSENTINO, JEAN-NÖEL STAELENS, BERNARD MARTEL, MARC FOURMENTIN, SONIA LOIACONO, GILLES CHANET, GIANGIACOMO TORRI, NADIA MORIN-CRINI

Simultaneous Removal of Inorganic and Organic Pollutants from Polycontaminated Wastewaters on

Modified Hemp-Based Felts.

HUSSEIN A. ALABDLY, INAS J. AL-NUAEMI, HUSSAM NADUM ABDALRAHEEM AL ANI,

SIMONA COTORCEA, AURELIA CRISTINA NECHIFOR

Removal of Toxic Phenolic Compounds from Wastewater Using Zeolite (4A) Prepared from Local Clays

Taken from the Slopes of the Tigris River.

ANANDAVELU KOTHANDAPANY, VISWANATH KRISHNAN

Investigating the Performance, Combustion and Emission Characteristics of PSZ Coated Diesel Engine

Powered by Bio-fuels.

YUAN WEI, YATING SUN, DAHUA LI, BINDA LU, MIAOHUA LIU, GONGGANG LIU, JINBO HU

Considerable Improvement in Fenton-like Degradation of MB Owing to $\mathrm{Ti}^{3+} / \mathrm{Ti}^{4+}$

Using Ion-doped Halloysite Nanotube Catalyst.

FITRY MULYANI, M. DIKI PERMANA, SAFRI ISHMAYANA, IMAN RAHAYU,

\section{DIANA RAKHMAWATY EDDY}

Optimisation of Zinc Oxide Nanoparticle Biosynthesis Using

Saccharomyces Cerevisiae with Box-Behnken Design. ...

NARCIS ANGHEL, MARIA VALENTINA DINU, FLORICA DOROFTEI, IULIANA SPIRIDON

Xanthan Matrix as Drug Delivery System.

NUSRAT SHAFIQ, FARAH YASMIN, SADIA NOREEN, ALINA SHAHZAD,

ZILL-I-HUMA NAZLI, SHAGUFTA PARVEEN, BASHARAT ALI, ZAHEER AHMAD,

MARYAM RASHID, MUHAMMAD BILAL

Phytochemical Profiling of Medicinal Plants Extracts and their Antioxidant

and Anticancer Potentialities Against Human Liver Cancer (Hep G2) Cell Lines.

WANGLAI DONG, LEI CHEN, HANZHAO YAN, ZIJIE ZHANG, ZHENG ZHOU

Thermodynamic and Kinetic Study on the Catalysis of Isobornyl Acetate by a Cation Exchange Resin an

Intensified Fixed-Bed Reactor.

THEODOR HARATAU, IOANA PRECUP, SIMONA STEFANESCU

Chemical Safety Management Training Hub for Downstream Users \& Distributers of Chemicals

SIDHARDHAN SUSAIAPPAN, ADISHKUMAR SOMANATHAN,

MANNAR THIPPU SULTHAN, IMMANUVEL PALIES MASILAMANI

Groundwater Quality Variation and Regression Analysis - a Case Study Around Municipal Dumpsite in India.

SALEH H. SALMEN, EMAN DAMRA, TAHANI AWAD ALAHMADI, SULAIMAN ALI ALHARBI

Green Synthesis, Characterization and Antibacterial Activity

of Silver Nanoparticles from Capparis Spinosa Leaf Extract.... 